\title{
特集【論説】 都市アメニティと不動産開発
}

\section{都市アメニティの保全と不動産開発}

Preservation of Urban Amenity and Real Estate Development

Yoshitaka AOYAMA : Graduate School of Engineering, Kyoto University

青山 吉隆*

The urban amenity is defined as urban space with attractive culture, history, nature, landscape and community, which is peculiar to each city. It may be destroyed by the real estate development or it may be well preserved. The center district of Kyoto city is being taken up as a case of the amenity problem. There are some troublesome problems with the preservation of Kyo-machiya (old town houses in Kyoto), which is confronted with the growing apartments development. This area is the excellent center of Kyoto in environment for both living and working. But high-density use of the land in this district is being promoted by the rational function of a land market. The necessary system of real estate development is proposed in order to preserve the urban amenity.

keywords : 都市アメニティ, 不動産開発, 京町家保全, 土地市場

urban amenity, real estate development, preservation of Kyo-machiya, land market

\section{1. 都市アメニティとは}

我が国が世界第 2 位の豊かな経済社会であるに もかかわらず，ヨーロッパのような魅力的な都市 空間のストックが少ないのはなぜだろうか。過去 の高度経済成長期を経て, 超高層オフィスビルや マンション, あるいは美術館, 博物館, 音楽ホー ルなど，それぞれ確かに単体としては優れたデザ インや機能を持つ建物が創造された。また高速道 路，高速鉄道，上下水道などの大規模なインフラ 整備が進んだ。我々の都市は非常に便利で, 安全 で, 清潔な空間であることは確かである。しかし 経済的な成功は巨大な機能的空間を造りだすこと はできても，必ずしも魅力的な都市空間を造るわ けではないらしい。諸外国から日本の都市を観る ためにやってくる観光客数はフランスの 16 分の 1 ,
支出額はアメリカの 25 分の 1 と非常に少ないこと が，そのことを物語っている。すでに高齢化社会 だというのに，高齢者，障害者などのモビリティ は十分には確保されていない。要するに，この人 工的空間はお金をかけた割には，魅力的でもなけ れば，人に優しくもないし，住み心地もそれほど 良くない。

戦後の都市づくりの過程で, まず人口と産業の 都市集中による需要増加に対応して住宅, 道路, 鉄道, 公園, 学校等々, あらゆる都市施設の量的 確保が最優先され, 便利さ, 安全さ, 清潔さなど 都市が備えておくべき基本的条件が目標とされた のは当然のことであった。そしてようやく都市政 策の背景は，この基本的条件を超える都市の魅力， すなわち優しさ, 住み心地, 働き心地, 美しさ, 文化性など, 新しい付加価值の重要性を認識でき 
る時代に入りつつある。私はこの新しい付加価值 を総括的に表現するために, それぞれの都市の個 性を生かし，文化と歴史と自然とコミュニティを ふまえた魅力を都市アメニティという概念で提案 したい。

だが都市アメニティの概念はまだ確立されてい ない。優れた都市アメニティは自然環境, 歴史的 建造物, 近代建築, 公園, 道路, 住宅などの人工 施設が空間に適切に配置され，デザインされるこ とによって創造されていく。たとえ極めて価值の 高い歴史的文化財であっても，それが高層ビル街 の中に孤立している環境には優れたアメニティが あるとは言えない。逆に，美しい自然に満ちた雄 大な風景も，そこに誰も住んでいない場合には， その空間を都市アメニティとは呼ばない。あくま でアメニティは人びとの生活にとっての環境であ る。さらにアメニティは美だけでなく，より広く， 静穏さ, 清浄さ, 文化性, 歴史性など, 生活の質 を快適にする多くの諸条件を含むと解釈すべきだ ろう。

都市アメニティは，ある空間に存在する多種多 様な都市の要素の量・質・配置に対して，ある都 市活動を行うに際して大多数の人々が主観的に感 じる共通の価值である。したがって，都市アメニ ティはさらにいくつかの機能に細分化できる。特 に都市計画の視点からは, 住環境, 職環境, 遊環 境としてのアメニティが重要である。アメニティ は相互に独立である。たとえば職環境アメニティ が良くても，住環境アメニテイが悪ければ，住民 が満足することにはならない。したがって住環境 アメニティ, 職環境アメニティ, 遊環境アメニティ は互いに代替できない。この代替できない 3 種類 のアメニティを総合したものが都市アメニティで ある。

都市アメニティが包括的な概念でありさらに階 層的な構造を持っているために，その定義は困難 であるが，一般的な特徴は次のようである。都市
アメニティは空間に固有の価值であり，それぞれ の都市空間に帰属している。この特徵が都市アメ ニティの価值を最終的に土地所有者に帰属させる ことになる。都市アメニティの価值は, 建築物な どの私的財と共に，公共施設の量・質・配置によっ て大きな影響を受ける。さらに都市アメニティは, 個人の価值観に依存するが，一方でその価值は 人々によって共有されるものである。価值の大き さに個人差があるとしても, 少なくともその都市 空間アメニティの価値については, 大多数の人々 によって共通の認識が保たれている。ある人に とって豊かなアメニティにあふれた都市空間は, 他の多くの人にとっても同様に価值がある。また 都市アメニティを構成する自然環境, 歴史環境, 風景などは自然, 文化財, 歴史的遺産などによっ て形成されるが，これらの多くは一度破壊される と再生が困難な不可逆財が多い。したがって，都 市アメニティには持続可能性という視点が不可欠 となる。都市は生産と消費の場であり, 住, 遊, 職，学，動の活動の場である。それぞれ異なった 活動に応じて，人々は都市アメニティに異なった 価值を付与する。この結果, 同一の空間が利用目的 によってそれぞれ異なった価値を持つことになる。

\section{2. 京町家集積地区の都市アメニティ}

すでに述べたように都市アメニティの概念を， 都市づくりの包括的な目標として位置づけている。 都市アメニティは新しい機能の整備や，あるいは 既存の機能を保全することによって創造されるか, あるいは破壊される。以下の京都都心地区でのア メニティ問題は保全と開発の調和にかかわる典型 的な事例である。

京町家が集積する職住共存地区では，ほとんど の大都市で失われてしまった伝統的な地域コミュ ニティが今も活きている。市民は歴史や文化を日 常生活の中で実感しながら, まちづくりの担い手 としての誇りを持ち，まちへの価值観が共有され 
ている。日本には伝統的な町家が単独で，あるい は一街区程度に残っている町は京都以外にもたく さん存在するが, この地区の百三十へクタールと いう規模と二万件を超える戸数の集積は貴重であ る。この地区には住環境としても，また職環境と しても優れたアメニティがあり,さらに京都中心 部にあって, 鉄道, バス, 自動車のいずれにとっ ても交通利便性に優れた位置にある。そして, 皮 肉なことに, 当然の成り行きとして, 土地市場は この地区を高く評価し，マンション地区として高 度利用し, 人口を増加させ, 便利な中心市街地と して再生するという，市場原理に沿った極めて合 理的な機能を果たしつつある。中心部の空洞化に 悩む地方都市から見ればうらやましい現象である。 だが，長期的には町家の消滅によって，貴重な京 都らしい魅力, アメニティ, コミュニティは失わ れ，便利さだけが残ることになる。京町家が私的 財である以上, 開発利益が存在する限り, 市場原 理にしたがって京町家はマンションや事務所や駐 車場に転換されていく。京都都心部には最近の 都心回帰の趨勢もあって依然として強いマンショ ン需要がある。また，その一方で，京町家は老朽 化が進み, 約半数の世帯が居住継続の問題点とし て, 維持・修繥費や耐震性・防火性をあげている など, 京町家の資産価值は年々低下傾向にある。

\section{3. 京町家からマンションヘの土地利用転換 の構図}

この土地市場に参加するのは, 土地供給者（京 町家を売却する地主), 土地留保需要者 (京町家所 有者), 土地需要者 (マンション・ディベロッパー), の 3 者である。ただし, 土地留保需要者が留保を あきらめたとき, 土地供給者に変わる。土地市場 におけるこの 3 者による土地利用転換のメカニズ ムは図ー 1 (a) で説明される。

この地域の京町家の土地面積を $\mathrm{S} と し$, 横軸OS によって表す。縦軸に地価をとり, 京町家の留保

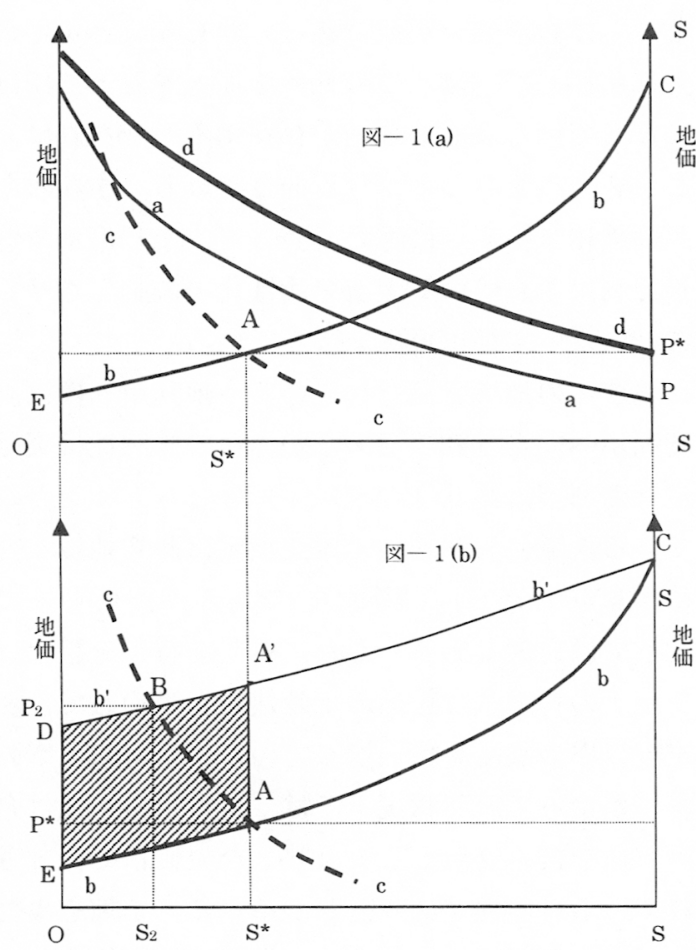

図一 1 京都家からマンションヘの土地利用転換

需要関数を $\mathrm{a}$ とする。この留保需要関数と総供給 関数SSとの交点Pが現在の地価である。地価が安 いほど売却せずに住み続けようとし，地価が高く なれば, 売却する人が増加するから, 供給関数 bb は, 留保需要関数を左右反転した形である。マン ション用地の需要関数をccとする。需要関数 $\mathrm{cc}$ と 留保需要関数aaを横軸方向に加えたddが総需要 関数である。総需要関数と総供給関数SSとの交点 $\mathrm{P}^{*}$ が新しい均衡点である。均衡の結果, 京町家用 地OSのうち, OS*がマンションに転換され, $\mathrm{S} * \mathrm{~S}$ 留保され, 地価はPからP*に上昇する。次 期では, $\mathrm{S}$ * Sを京町家の土地面積として, 新しい マンション用地需要に対する売買が繰り返される。

この変化は経済的には, 土地が高度に利用され, 有効に活用される方向に転換されたことを意味し ている。これは土地市場において, 最適な土地資 源の配分が促進されていくことであって, 私的財 
としては合理的な転換である。むしろほとんどの 大都市都心部では，この転換を促進する上で妨げ になっているような規制が存在するのであれば, これを緩和することが合理的とされる。すなわち 規制緩和を積極的に進めていって，未利用地や低 層で利用されている土地を活性化・流動化させる ことによって都市再生を図っている。

現在この地域で進行している土地利用転換は高 度利用へ向かう動きであるが，この必然性は実は 現行の都市計画制度の中にすでにビルトインされ ている。職住共存地区の用途指定は商業地域, 容 積率は400\%, 高さ制限 $31 \mathrm{~m}$ であるが, 京町家に とっては過大である。これに対して特に分譲マン ションの約半数は複数の土地建物を集約して, 法 定容積率の限度を使い切っている。京町家上空の 容積が余っている状況下では, 京町家の土地は余 剩容積を含み資産として反映しない価格で売却さ れている可能性があり，しかる後に，土地を集約 して法定容積率いっぱいのマンションを建設して， この含み資産を実体化すれば，開発利益はさらに 大きくなる。したがって，この地域の商業地域と いう用途指定は, 他の多くの大都市の都心部がそ うであるように, 経済効率が最も重要だという結 果をもたらしており, 高層のマンションもしくは 事務所が相応しく, 京町家は非効率的であり, 除 却されるべき存在であるかのように見える。要す るに, この用途指定には, この地域空間を他の都 市と差別化して，この地区のアメニティを育もう という意図は見えない。

この土地市場における土地の高度利用は都市ア メニティにどのような影響を与えたかを図ー 1

（b）を用いて説明する。京町家集積が良好な都市 アメニティを形成し，マンション用地に転換され る前にはCDEで囲まれる面積の社会的便益が存 在していたとする。OS*の町家用地の減少による 社会的損失額は斜線部分で表される。社会的費用 の存在を考慮すれば, 均衡点はBになるべきであ
り, そのときマンションへの転換用地はOS 2 に減 少し, 地価は $\mathrm{P}_{2}$ に増加する。このプロセスを放置 して市場の流れに任せておくとどうなるか。まず 都市景観の視点では, マンションが建てば建つほ ど, 京町家が減少していくから, 景観や風通しが 悪くなり, 地域コミュニティが維持できなくなり, 歴史的町並みが崩壊し, 都心部の住空間としての アメニティが徐々に低下していくだろう。マン ション需要が全てこの都心部のアメニティに依存 している場合には, 需要関数ccは左方に移動し, いつか開発利益が他の地域より少なくなった時点 で開発が止まり, 理論上は市場均衡に至る。

しかし, 一方で, この地区のマンション需要の 中には，住環境アメニティの良さよりも，むしろ 都心部としてのアクセシビリティの良さに価值を 見いだす世帯がある。この地区は通勤, 通学, 買 い物, その他日常生活の全般に渡って, 極めて便 利である。そして，この地区には中心市街地とし ての魅力とアクセシビリティとは残っているから， アクセシビリティ重視型の需要は, 京町家の集積 が消滅しても衰えず, この需要に対応して, マン ションの供給が続き, その結果, 多くの京町家が 駆逐され, ありふれた都市景観へと変貌すること になる。

経済的な視点においては, マンション建設後に は, 京町家によって形成されていた住環境アメニ ティが悪化し, 少なくとも住環境重視派の留保需 要は減少するから, 図-1（a）の供給曲線は右方 に移動して土地価格が低下する。つまり京町家所 有者と新規マンション所有者の資産価值は低下し (マンション購入者も含まれることに注意しょう)， 実質的な損害が発生する。短期間の内に最も直接 的な被害を受けるのは, そこで職住を暮らす人々 である。ただし，先に述べたように，アクセシビ リティ重視派の需要は衰えないから, 景観は悪化 しても都心居住が促進され，多くの都市と同じよ うに，土地資産価值はアクセシビリティに相応し 
い水準が下限になる。

社会的な視点においてそこで起きている変化は, 高齢世代から若年世代への交代と定住人口の増加 であり，新しい世帯の地域コミュニティへの流入 である。都心部の夜間人口の増加はにぎわいをも たらし，郊外部からの交通需要を減少させるなど 多くの社会的便益をもたらしている。新しい世帯 の多くが，先述のように，住環境アメニティより も，アクセシビリティを重視する価值観を持って いる場合には，ここでの社会的な課題は，この伝 統のある地域コミュニティの持続的発展の可能性 である。都市の構造から見ると,木造密集住宅か ら鉄筋あるいは鉄骨中高層住宅への変換であり， 防災防火性能は向上している。

\section{4. 京町家アメニティの保全と不動産開発}

都心地区の人口増加を期待しながら，一方でこ の地区固有の都市アメニティを保全するためには， 外部不経済を出来るだけ土地市場に内部化させる ことである。開発利益が正である限り，マンショ ン開発が進むから，これを食い止めるためには開 発利益を増大させない対策が必要である。理論的 には，(1)京町家の現在価值を上げること，(2)マン ションの価值を下げること, (3)建替費用を上げる こと，の 3 種類に分類できる。分類(1)の対策は, すなわち京町家の利用価值を高くすることである。

住居専用の京町家がデザインの優れたレストラ ンやショールームなど魅力的な商業施設にリ ニューアルされるのがその典型である。こうした 再生によるいわゆる町家ブームが持続すれば，京 町家の利用価值が高まることによって, 留保需要 曲線が右方向に移動し, マンションへの土地供給 が減少することになる。分類(2)の対策は, マンショ ンの総販売価格を下げることである。これは開発 利益を抑えるために最も直接的な手段である。容 積率と高さの規制を強化する。このいわゆるダウ ンゾーニングによって, 容積率が減少するから,
価值は低下し開発利益は減少するはずである。分 類(3)対策は，マンションの建設費用を高くする ことである。すでにこの都心地域では高度利用の 進行が著しい。むしろマンションと京町家の共存 を図るべきであり，京町家によって形成されてい た住環境アメニティを破壞するのではなく，さら に向上させるために，デザインの優れた，この地 区に相応しいマンション供給を促すのが妥当であ る。したがって，この地区を美観地区に指定して デザインコストを負担させる，あるいは環境基準 を厳しくして環境創造コストを負担させるなど， 共存コストを建設費用に内部化させることによっ て，フリーライダーを排除する。

\section{5. むすび}

私的財である京町家の集積を土地市場の経済义 カニズムだけに任せていては保全できないのは明 らかである。京町家はマンションや小規模駐車場 によって駆逐され，集積は現在も縮小しつつある。 一方で，デザインの優れたマンションへの転換が 進むこと自体は, 都心居住の促進の視点からは評 価すべきである。所有者の高齢化に伴う相続問題 は土地の地上げを促進する大きな要因であり，全 体としては社会問題であるが, あくまで個人的事 情である。この地区の開発と保全は, 経済, 社会, 景 観, 伝統, コミュニティなど様々な要素が絡み合っ た極めて複雑で解決の困難な問題である。

結局，それぞれの都市のアメニティを形成して いる重要な要素のうち, 経済メカニズムによって 保全できない可能性のある要素を明確にしておく ことが少なくとも必要である。

\section{参考文献}

1) 青山吉隆編著：職住共存の都心再生，2002年11月, 学芸出版社。

2 ）青山吉隆, 中川 大，松中亮治共著：都市アメニ ティの経済学，2003年10月，学芸出版社。 